\title{
Brand experience manual: bridging the gap between brand strategy and customer experience
}

\author{
Mauricy A. Motta-Filho ${ }^{1}$ (D)
}

Received: 23 April 2019 / Accepted: 6 June 2020 / Published online: 16 June 2020

(c) The Author(s) 2020

\begin{abstract}
The importance of customer experiences in developing strong brands is broadly acknowledged in the Branding literature. Yet, the divide between the functions managing the brand and those responsible for devising the interactions through which customers experience the brand persists. This paper aims to bridge the gap between Brand Strategy and Customer Experience by introducing the concept of the Brand Experience Manual. Through practice-based design research, this paper describes the development of a Brand Experience Manual over four iteration cycles. Throughout this process, this paper explores ways of conveying the experience proposition made by the brand, developing a framework for defining and a tool for communicating the Brand Experience Proposition to the teams responsible for the New Service Development. Additionally, this paper offers a theoretical basis for the advancement of a customer experience-centric approach to Branding.
\end{abstract}

Keywords Brand experience · Practice-based design research · Service design · Branding $\cdot$ Design for brand experience

JEL Classification M31 · M39 $\cdot$ L19

\section{Introduction}

Customer experience plays an important role in brands and the formation of brand equity (Aaker 1991; Grönroos 2007; de Chernatony 2010; Kapferer 2011; Keller 2013). Brands emerge from the continuous interactions between the proposition made by an organization, as manifested through its offerings, and customers' experiences resulting from their encounters with these value propositions (Iglesias and Bonet 2012). In this context, Service Design offers a user-centric approach to

Mauricy A. Motta-Filho

m.alvesdamottafilho@utwente.nl

1 Department of Design Production and Management, Faculty of Engineering Technology,

University of Twente, Drienerlolaan 5, 7522 NB Enschede, The Netherlands 
service innovation (Yu and Sangiorgi 2014) that supports the development of the service offerings that bring the brand to life. Conversely, brands' strong link to business strategy (Aaker and Joachimsthaler 2000) can help inform Service Design processes, for "if service design is to be used in substantial and not in a decorative manner it has to be connected to the business strategies" (Mager 2009, p. 35).

Greater integration between Service Design and Branding practices may benefit both fields. However, a study by Forrester Research found that only $18 \%$ of organizations use the brand to inform customer experience strategy, indicating a gap between the functions that manage the brand and those that design the interactions through which customers experience the brand (Munchbach 2014). A similar issue was found in a study addressing the usability of brand manuals for the design of service experiences (Motta-Filho 2012). Because "qualitative brand descriptions are transformed into value-based design features" (Karjalainen and Snelders 2010, p. 8) during the early stages of the New Services Development (NSD) process (Clatworthy 2013), it is essential that design teams have proper brand input. Yet, Motta-Filho found that contemporary brand manuals do no address these needs, as they do not inform the experience the brand seeks to deliver.

To facilitate the translation of brand strategy into customer experience, this research addresses the gap between the brand strategy and the NSD process by developing a new kind of brand manual, one that focuses on the experience proposition made by the brand (i.e., Brand Experience Proposition) and which is capable of informing the teams responsible for the NSD process (i.e., NSD teams) of the experience they should design for: a Brand Experience Manual. The present paper thus answers the question, "How can we bridge the gap between the brand strategy and the NSD process?" using practice-based design research (Nowotny 2004; Saikaly 2005) exploring (a) how to translate the brand strategy into an experiential expression of the brand proposition and (b) how to convey this Brand Experience Proposition to the NSD teams.

The present paper contributes to the scant research on the intersection of Branding and Service Design (Clatworthy 2012), providing tools to bridge the gap between brand strategy and the design process, and defending a stronger link between the fields. Using practice-based design research to develop a Service Design based framework, this paper provides a variation of Research through Design, which, when applied in the business context, supports the creation of new knowledge in the context of application (Nowotny 2004). By making the design project an integral part of the research process (Saikaly 2005; Sevaldson 2010), such a methodology has the potential to answer questions that focus not only on understanding the world but also on proposing new solutions; thus, the methodology is particularly adequate to answer the research question.

The following section presents the theoretical basis on which the present research builds. Next, the practice-based design research methodology is further detailed. The fourth chapter describes the research process, and the subsequent sections introduce the main design outcomes (i.e., the Brandslation framework and Brand Experience Manual). Then, the research findings emerging from the design interventions are discussed, and the last chapter concludes by reviewing the outcomes and suggesting an agenda for future research. 


\section{Theoretical review}

The idea of designing brand-based customer experience is not new (Schmidt and Ludlow 2001; Shaw and Ivens 2002; Smith and Wheeler 2002; Schmitt 2003; Merrilees 2017). Over 17 years ago, Smith and Wheeler (2002) proposed the concept of Branded Customer Experience as "creating a unique experience through every interaction your customers have with your people, processes, and products which differentiates your brand." Similarly, Shaw and Ivens (2002, p. 11) argued that the customer experience should reflect the brand; for the authors, "the people delivering the customer experience should be delivering a branded customer experience." Yet, while various authors have discussed the intersection between customer experience and the brand, their managerial focus delivers high-level, generic advice with limited practical and operational insight. Abbing (2010) and Clatworthy (2012), however, are two remarkable exceptions.

Writing from a practitioner's perspective, Abbing (2010) proposes Brand-Driven Innovation as an approach for using the brand as a resource to help designers, developers, researchers, and engineers develop new products and services. Throughout his book, Abbing offers a model and examples of how to use a brand as a driver of innovation. In the academic literature, Clatworthy (2012) addresses the gap between brand strategy and Customer Experience via Service Design. Building on Semantic Transformation (Karjalainen 2004), Clatworthy focuses on the early stages of the NSD process, proposing a model to help design teams translate the brand DNA into the service's tone of voice, behaviors, and touchpoints with which customers interact, and which influence their experiences.

Hence, because few references on the topic are available, instead of reviewing the existing literature, this chapter focuses on the theory that supports the research. This approach means integrating key concepts related to Branding, Experience, Service Design, and Service (Dominant) Logic. ${ }^{1}$

\subsection{Brand and experiences}

In the literature, brands are often conceptualized from two main perspectives: that of the company and that of customers. From the company's perspective, brand identity is a powerhouse of meanings (Sherry 2005), "a cluster of functional and emotional values that enable a promise to be made about a unique and welcomed experience" (de Chernatony 2010, p. 17), and which represents how the organization wants customers to perceive the brand (Aaker 1996; Grönroos 2007; Plumeyer et al. 2019). From the customers' standpoint, the brand image is a depository of the meanings associations emerging from their interactions with the brand manifestations (Aaker 1991; Sherry 2005; Semprini 2006) and is the main source of brand equity; that is,

\footnotetext{
1 Design for Service literature does not firmly distinguish the influence of Service Logic (Grönroos 2006, 2008) from Service Dominant Logic (Vargo and Lusch 2004, 2008, 2016). Therefore, this text will adopt the "Service (Dominant) Logic" term.
} 
the "differential effect that brand knowledge has on consumer response to the marketing of that brand" (Keller 2013, p. 69).

Brand equity formation begins with the customers interacting with the proposition made by the organization and evolves through the development of behaviors (e.g., loyalty). These behaviors create a higher market share and positive cash flow for the organization (Kapferer 2011). The brand value is thus based on its power to influence customers' perceptions and attitudes (Calkins 2005). In that sense, the brand is a repository for stakeholders' collective perception from their past experiences with the brand (Semprini 2006; Merz et al. 2009); "the focal point for all the positive and negative impressions created by the buyer over time as he or she comes into contact with the brand's products, distribution channel, personnel and communication" (Kapferer 2011, p. 19), and from which the organization may extract or lose equity (Aaker 1991; Keller 2013).

Yet, organizations cannot control how customers perceive the brand (Meenaghan 1995). Despite not being able to control customers' perception, organizations can influence the interactions through which customers experience the brand (Berry 2000; de Chernatony et al. 2003; Zomerdijk and Voss2010). As the brand value is based on stakeholders' collective perception (Merz et al. 2009)_and the meanings associations linked to the brand (Aaker 1991) — strengthening the brand requires developing service interactions that deliver the right meanings and associations to customers (Batey 2008). In other words, brand-based interactions that deliver the brand promise to the customers. It is through these interactions that the customer will decode the brand proposition embedded in the characteristics of the service offering, linking them back to the brand name; the stronger the associations, the stronger the brand (Keller 2013).

For Karjalainen (2004) this process of translating the brand proposition into the features of the design object is called Semantic Transformation. Building on Peirce's triadic semiotics (Santaella 2008), the concept depicts brands as a meaning proposition (object) communicated to customers (interpretant) through the qualities and characteristics of the design object (representamen), which operate as a manifestation of the brand (Karjalainen and Snelders 2010). The goal is to embed the brand meanings into the interactions through which the customer experiences the brand. As Meyer and Schwager (2007, p. 3) suggest, "a successful brand shapes customers' experiences by embedding the fundamental value proposition in offerings' every feature."

\subsection{Meaningful brand experience}

The concept of experience can be defined from different perspectives. Kahneman (2011) distinguishes the experience of the experiencing self-i.e., the experience as perceived in the moment of the interaction-from the recalled experience of the remembering-self. From a phenomenological point of view (Helkkula 2011), experiences refer to the "internal and subjective response customers have to any direct or indirect contact with a company" (Meyer and Schwager 2007, p. 2). For Sundbo and Sørensen (2013, p. 2), "experience is something that happens in people's minds, it 
is determined by external stimuli and elaborated via mental awareness." That is, to exist, experiences need an external trigger that activates the human senses (Schmitt 1999), generating a response.

For Pine and Gilmore (1998), experiences are a type of offering; the next stage in the economic value progression and are as distinct from services as services are from goods. Although the authors acknowledge the phenomenological nature of the concept, their focus on staged experiences creates a bias towards a suppliers' perspective, where the company is seen as an experience provider, which can be associated with hedonic consumption (Holbrook and Hirschman 1982) and extraordinary occurrences (Arnould and Price 1993). The advantage of a phenomenological point of view is that it encompasses experiences with all kinds of products-be they an experiential offering (Pine and Gilmore 1998) such as a theater play, an ordinary service such as telecommunications, or a good.

From a phenomenological perspective, any interaction creates an experience for the customer, whether the organization is in the business of experiential offerings or not (Morrison and Crane 2007; Johnston and Kong 2011). Hence, since brands emerge from the continuous interaction with the customers (Iglesias and Bonet 2012), regardless of acknowledgment or intention, organizations are always engaged in a branding process (Ostrum et al. 1995). Consequently, to actively manage the brand, organizations must focus on customers' experiences and the interactions that deliver the brand proposition. In that sense, a Meaningful Brand Experience does not necessarily imply an extraordinary offering (Pine and Gilmore 1998), but an interaction that conveys the brand meaning through its features (Karjalainen 2004; Clatworthy 2012).

Through the interactions with these meaning-led interfaces, customers decode the brand proposition, attributing the interpreted meanings back to the brand name (Aaker 1991; Karjalainen 2007). Because "people do not perceive pure forms, unrelated objects, or things as such but as meanings" (Krippendorff 1989, p. 12), customers' experiences with a brand are not merely good or bad (Kahneman and Riis 2005) but a reflection of the customers' interpretation of the meanings communicated through the brand manifestations (Batey 2008). In other words, service interactions mediate the brand meaning to customers and, conversely, the brand should inform the development interactions through which customers experience the brand.

\subsection{Service design and brand experience}

In New Service Development (NSD) literature, service design (Goldstein et al. 2002; Tatikonda and Zeithaml 2002) is referred to as the early stages of the process, when the service concept is created, defining the value proposition made by the organization and informing the implementation of the enablers of the service interactions (Edvardsson and Olsson 1996). In the last 25 years (Manzini 2009), Service Design (in capital letters) has emerged as a human-centered, holistic and iterative approach to service innovation ( $\mathrm{Yu}$ and Sangiorgi 2014; Blomkvist et al. 2010), which builds on "a designerly way of working when improving or developing people-intensive service systems through the engagement of stakeholders" (Segelström 2013, p. 27). 
Departing from a tradition based on operation management, marketing, and information and communications technology (Shostack 1977; Kimbell 2009; Patrício et al. 2019), Service Design "represents the application of design as a creative and culturally informed approach to services" (Clatworthy 2013, p. 16), focusing on the users' and customers' experiences (Wetter-Edman 2011). To facilitate the design of immaterial activities and the orchestration of touchpoints across the customers' journey (Kimbell and Blomberg 2017), Service Design uses visual tools and enactive, iterative and collaborative methods (Moritz 2005; Mager 2009; Stickdorn 2010) that support the coordination of the different silos and stakeholders (Kimbell 2009) to develop new service offerings (Clatworthy 2013).

Due to its processual nature, services only emerge in the interaction with its users (Johnston and Kong 2011). That is, they are constantly (co-)designed during the service provision (Evenson and Dubberly 2010), while the value cocreating interactions take place (Holmlid et al. 2017). In that sense, Service Design must be concerned not only with the development of the service offering as an idea but also with the translation of the service concept into the enablers of the customer experience. Through a human-centered, holistic, and iterative approach, Service Design supports the exploration, ideation, prototyping, testing, and implementation of the new service offerings and the interactions that deliver its value proposition to the customers (Blomkvist et al. 2016; Patrício et al. 2019).

By integrating the resources that support the service interactions (value co-creating systems; Kimbell and Blomberg 2017), Service Design has the potential to facilitate the development of the interfaces (Secomandi and Snelders 2011) and offerings (Clatworthy 2013) through which customers experience the brand, bringing the brand proposition to life. On the other hand, it is also important to acknowledge the contribution Branding offers Service Design by providing a stronger link to business strategy (Aaker and Joachimsthaler 2000; Mager 2009).

\subsection{Design for brand experience}

Service Design literature has traditionally focused on the front end of the service innovation process; that is, developing the service as a concept, devising the service encounters and touchpoints, and the orchestration of the customer journey (Blomkvist et al. 2016; Yu and Sangiorgi 2018). More recently, with Service Design integrating Service (Dominant) Logic concepts (Vargo and Lusch 2004, 2008, 2016; Grönroos 2006, 2008), Design for Service emerged as an approach that "acknowledges the indeterminacy of services as an object of design" (Sangiorgi 2012, pp. 98-99) and that recognizes that what is being designed is a platform that supports value cocreation processes (Vargo et al. 2008; Manzini 2011; Kimbell 2011).

In Service (Dominant) Logic, service (in the singular) refers to the application of skills and knowledge to support value cocreation for the benefit of another (Vargo et al. 2008; Grönroos and Gummerus 2014), where value is cocreated in the use context and is determined by the beneficiary; i.e., "value is idiosyncratic, experiential, contextual and meaning laden" (Vargo and Lusch 2008, p. 7). In that sense, the organization doesn't create value but offers value propositions, which supports value 
cocreating processes in the interactions between the customers' and the company's resources (Vargo 2008). Grönroos and Voima (2013) call this intersection moment joint sphere; when the company, as a facilitator, interacts with the customer, supporting value co-creation.

The role of the organization is thus to integrate resources, arranging them in new configurations that have the potential to facilitate interactives processes (Grönroos 2008) that cocreate value in the use-context. Value is cocreated as the actors' resources are combined during the service interactions (Holmlid et al. 2017). As a consequence, in order to translate brand strategy into customer experiences, organizations must focus on devising brand-based value propositions and on developing the prerequisites that enable the customers' experiences (Zomerdijk and Voss 2010). An Experience-Centric Branding (Merrilees 2017) can thus build on a Service (Dominant) Logic view of Service Design, supporting an experiential approach to semantic transformation (Karjalainen 2004; Clatworthy 2012).

Such approach should focus on (1) understanding what is the experience the brand wants to deliver the customers (Motta-Filho 2012); (2) translating such experience on a service concept during the early stages of the Service Design process (Clatworthy 2012); and (3) integrating the resources that enable the service concept (Vargo and Lusch 2004, 2008, 2016; Patrício et al. 2011; Overkamp and Holmlid 2016; Holmlid et al. 2017). In this paper, we specifically address the first challenge, exploring how to define and communicate the Brand Experience Proposition to the teams that will develop the interactions through which the customers experience the brand.

\section{Methodology}

This paper reports on research that explored how to facilitate the translation of brand strategy into customer experience by specifically addressing the gap between the brand strategy and the NSD process. Due to the nature of the problem-which required the creation of new knowledge in the application context - a practice-based design research (Nowotny 2004; Saikaly 2005) based on an action research strategy (Lau 1997) was employed. In practical terms, this meant engaging service designers, corporate partners and experts in related fields as active participants in a transdisciplinary design process (Gibbons et al. 1994; Kindon et al. 2007; Dunin-Woyseth and Nilsson 2011) aimed at devising a solution for the given problem.

Throughout the design iterations, knowledge was coproduced following an approach similar to Research through Design (Frayling 1993; Jonas 2007), where the design iterations were central to the research. Yet, different from traditional views of Research through Design that frame the design outcome mainly as part of the process (Fallman 2007; Stappers and Giaccardi 2017), this study considers the produced artifact as a key contribution. This approach is in line with new modes of knowledge production (Gibbons et al. 1994; Dunin-Woyseth and Nilsson 2011) that extend beyond academic boundaries to acknowledge the role of design research in both producing new knowledge and improving the real world (Jonas 2007). 
In Mode 2 of knowledge production (Gibbons et al. 1994), research is carried out in the application context with the active participation of the communities of interest. Knowledge creation is approached in a broader and transdisciplinary social and economic context where the designed artifact can be considered a new form of knowledge in itself. Such a practice-based approach may be confused with other empirical processes. However, because the research focuses on the development of a new artifact-rather than analyzing existing ones, or changing the social and cultural configurations of the situation (participatory action research; Kemmis and McTaggart 2008) — it is arguably situated within a broader Research through (by; Sevaldson 2010) Design (Frayling 1993; Jonas 2007) tradition. In this way, the present paper raises a debate on practice-based design research modes where the artifact is at the same time the outcome and the means for producing knowledge in and through practice.

To structure the iterations through which the researcher engaged in "an empirical and logical problem-solving process involving cycles of action and reflection" (Reason and Bradbury 2008, p. 4), this study adopted action research (Susman and Evered 1978; Crouch and Pearce 2012) as research strategy (Lau 1997). In that sense, the design project was an integral part of the research process (Saikaly 2005; Sevaldson 2010), where the researcher was an active member of the design team. Such a first-person perspective has "the potential to provide findings unattainable with only an outside perspective" (Fallman 2008, p. 17), producing results that are relevant for both theory and practice (Crouch and Pearce 2012).

As practice-based research (Saikaly 2005) aimed at supporting the coproduction of knowledge in the context of practice (Gibbons et al. 1994; Dunin-Woyseth and Nilsson 2011), this paper builds on design research to support the creation of re-useable and communicable knowledge (Cross 1999). Reflective Practice (Schön 1982) is thus adopted as the epistemological choice, as it is regarded as well-suited for design research (Cross 2010). Moreover, reflective practice is particularly convenient, as it can be easily integrated into the iterative cycles of action and reflection that characterize action research (Susman and Evered 1978; Reason and Bradbury 2008).

Building on the concept of frame experiment (Schön 1982), abductive reasoning supported the creative leaps necessary to reframe the design problem (Cross 2010; Crouch and Pearce 2012), enabling the development of the new solutions and ideas that inform the research. Qualitative methods helped operationalize the research in a setting where the researcher was the main instrument for data analysis and collection (Merriam 2002; Pinto and Santos 2008). Primary data collection methods included observations, semi-structured interviews, and workshops (as a collaborative and participatory quasi-focus-group interviewing method; Gaskell 2008), and secondary (marketing) documentation was used as supplementary material (Creswell 2009).

\section{Practice-based design research process}

The present research combines the action research process proposed by Susman and Evered (1978) with Crouch and Pearce's (2012) to operationalize the design iteration through which knowledge is built. Combining both frameworks provided a stronger 


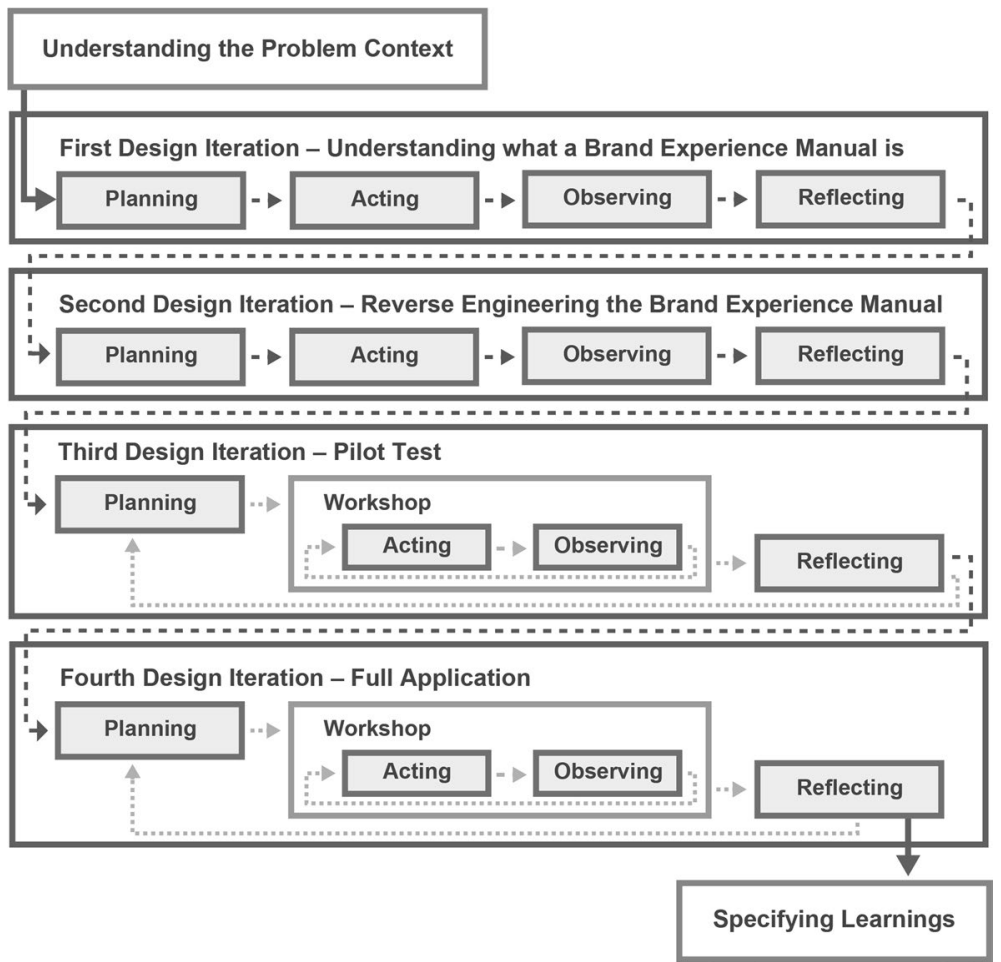

Fig. 1 Research iteration cycles (Motta-Filho 2017)

structure by integrating Susman and Evered's academic rigor-which specifies the stages for understanding the problem context (diagnosis stage) and for reflecting on the research outcomes (specifying the learning stage)—with Crouch and Pearce's design orientation (Fig. 1).

In the next sections, the research stages are briefly described, following an action research structure where each stage informs the next one. In this sense, the design iterations can be understood as a sequence of "case studies" that build upon each other one at a time. However, different from traditional case studies, the action research stages do not focus on studying existing business cases, but on creating new solutions through a collaborative transdisciplinary design process.

\subsection{Understanding the problem context}

The first stage of the research focused on understanding the wider research context; that is, exploring how to facilitate the translation of brand strategy into customer experience. Building on the concept of Semantic Transformation (Karjalainen 2004), and more specifically on Clatworthy's (2012) adaptation of the concept to service context, it was understood that the brand is translated into the enablers of the customer experience during the New Service Development (NSD), when 
"qualitative brand descriptions are transformed into value-based design features" (Karjalainen and Snelders 2010, p. 8).

It is therefore essential that the teams working on the NSD process have adequate brand input, informing which experience they should aim at designing. However, what constitutes an adequate brand input is as yet unknown. Thus, a research focused on exploring the usability of contemporary brand manuals for the design of service experiences was carried out through a series of 13 semi-structured interviews with Branding and Service Design consultants from 5 different countries (Motta-Filho 2012). The goal was not only to map existing brand input but also to understand how design teams address and use a brand in the development of new services.

Findings from this early exploration showed that existing brand manuals were not adequate for the design of service experiences, as they focused primarily on corporate visual identity (Kapferer 2011), describing the brand values in a very vague fashion. It was also observed that although some organizations had design manuals, these essentially provided detailed descriptions of the built environment and resembled a tridimensional corporate identity manual. Accordingly, to cope with the lack of adequate input, service designers often had to go through a process of decoding the brand proposition from different types of manifestations (Semprini 2006) in a context where there were seldom enough resources to support an adequate brand study (Motta-Filho 2012).

This initial exploration thus set the boundaries of the research on the gap between brand strategy and the NSD process by revealing two issues: from a Branding perspective, there is a lack of structured means to convey the experience the brand seeks to propose to customers (i.e., Brand Experience Proposition). From the Service Design perspective, the need to decode the brand on an ad-hoc basis increases the risk of interpretation biases, which could lead to the development of unaligned interactions, thus diluting the brand. To bridge the gap between brand strategy and the NSD process and to convey the Brand Experience Proposition to the design teams, a new type of brand manual is required: a "Brand Experience Manual."

\subsection{First design iteration: understanding what a brand experience manual is}

After defining a path to address the research problem, an exploratory and generative practice-based design research process (Sevaldson 2010) was used to develop the concept of Brand Experience Manual in collaboration with two corporate partners $^{2}$ and master's degree students from the Oslo School of Architecture and Design (AHO). On this occasion, the students acted as lead designers of their own projects, and the researcher (author) supervised the process as their tutor. Such an experimental approach was essential to kick-starting the project, enabling the quick prototyping of solutions in a context where little was known about the design outcome.

The project was developed during a two-month segment of the Service Design 2 course. The students were divided into two groups, each working with a corporate

\footnotetext{
${ }^{2}$ A telecommunications multinational and a large logistics conglomerate, both in Northern Europe.
} 
partner, and were free to design the Brand Experience Manual as they saw fit. Lectures were structured to provide the students with the necessary knowledge to support the design process and included key theoretical concepts, exercises, and presentations from experts in Branding and Service Design. The course syllabus provided recommendations and the researcher played an active role, joining the design process as participant-observer (Adler and Adler 1994). Discussion with the students showed that despite minor confusion in the early stages, both teams understood the task adequately.

Analysis of the outcomes showed a clear distinction between the approaches of the two student groups. Whereas one team approached customer experience as a phenomenon resulting from the interactions with the organization, thus addressing customers' holistic experience with multiple touchpoints, the other team focused on how the brand values were externalized through corporate actions, thus describing the desired experience through a series of distinctive values. These differences resulted in the development of two rather unique views, which helped the researcher attain a richer understanding of what a Brand Experience Manual could be like, and how to communicate the Brand Experience Proposition.

\subsection{Second design iteration: reverse engineering the brand experience manual}

Building on the outcomes of the students' projects, this second stage aimed at making the process of devising the Brand Experience Manual explicit, structuring a replicable framework that allowed further exploration of how to define the Brand Experience Proposition and how to convey it. Preparations began in tandem with the last steps of the previous stage. As the objective was to build on the outcomes from the previous iteration, two students (one from each group) were invited to participate, assisting the (author-) researcher in the design process.

Different from other iterations in the research, this design process was conducted without the participation of an external partner. In this way, to base the project in a real-world situation, data from the student projects were used. Building on the process used (implicitly) by students in the previous iteration, the design process began with a series of simulated workshops, which crossed the data from various stakeholders seeking insights that could be used to inform the Brand Experience Proposition. This exercise yielded four key intersections:

- Employee experience-between the company and the employee

- Brand image-between the company and the customer

- Service experience-between the employee and the customer

- Future scenario-between the company and the competitive environment

Insights emerging from these intersections were condensed into four reports and later organized and clustered as adjectives that helped to describe the quality of the interactions. These qualities were then grouped into Personality Traits, which were then translated into Behaviors (enablers of the desired qualities). The resulting Brand Experience Manual explained the Brand Experience Proposition through 


\begin{tabular}{|c|c|}
\hline Pre-Workshops & Gather Relevant Information for Following Workshops \\
\hline Workshop 1 - Experience Audit & Understand the Current Experience \\
\hline Workshop 2 - Moving Towards the Personality & Define the Service Personality Traits \\
\hline Workshop 3 - Expressing the Service Personality & ty Define the Brand Experience and Service Personality \\
\hline External Development - First Prototype & First Draft of the Brand Experience Manual \\
\hline Refinement Meeting & Refine the First Draft of the Cookbook \\
\hline External Development - Final Prototype & Final Expression and Brand Experience Manual \\
\hline
\end{tabular}

Fig. 2 Brandslation framework as planned for the third iteration (Motta-Filho 2017)

its components, using the process's data to detail the description. This approach resulted in a very hierarchical structure, which was considered too conservative and, in many aspects, too similar to existing brand manuals.

To help the Brand Experience Manual better express the desired experience, visualizations of the enactment of the Personality Traits/Behaviors pairs were developed with the help of external consultation. During this collaboration, the consultant suggested the use of Design Principles as guidelines that could help inform the NSD teams how to design for the desired Behaviors. The combination of Design Principles and the visualization of the behaviors offered an initial view of the nature of the Brand Experience Manual, thus clarifying how to convey the Brand Experience Proposition.

The goal of this iteration was to structure a replicable framework to define the Brand Experience Proposition and to advance the Brand Experience Manual. Throughout the design process, the interactive nature of experiences became explicit, as highlighted by the four key intersections. The specifications of these intersections played a central role in developing the process involved in defining the Brand Experience Proposition—named Brandslation-forming the core of the final framework.

\subsection{Third design iteration: pilot test}

With the support of a corporate partner, ${ }^{3}$ a pilot test was carried out to further advance the Brand Experience Manual while empirically testing and improving the framework to devise the Brand Experience Proposition (i.e., Brandslation). The iteration evolved throughout a series of three workshops (Fig. 2) and three external (non-collaborative, design-driven; Verganti 2009) development phases. Due to the pilot nature of the iteration and the limited resources available, the planned framework was shortened, focusing on devising and testing those parts responsible for defining the Brand Experience Proposition in collaboration with key stakeholders from the partner corporation, leaving the research stages for a later time (insights from another design project were borrowed to inform the process).

\footnotetext{
3 A logistics conglomerate in Northern Europe. On this occasion, the project focused on an offering aimed at small and medium-sized online shops.
} 
When the workshops were concluded, the researcher worked with two student assistants to develop the Brand Experience Manual and to elaborate the Design Principles, which were similar to the previous iteration: guidelines meant to summarize key recommendations for the NSD teams. Once refined, the Design Principles were illustrated by a short movie telling the story of Jane-a fictional character-and her journey throughout the service. The Brand Experience Manual was composed in tandem, explaining the link between Jane's story, the Design Principles, and the Personality Traits that informed its development. As in the previous version, adjectives (Qualities) were used to detail the Service Personality Traits, Behaviors to enact the Personality Traits, and Actions to explain the Behaviors.

Throughout this process, a collaborative and transdisciplinary codesign (Ehn 2008) process for devising the Brand Experience Manual was piloted, helping to advance the concept, improving the Brandslation framework, and extending the investigation on how to convey the Brand Experience Proposition. However, due to the use of borrowed insights, the Data Gathering process still needed to be structured as a Service Design approach. Moreover, the expressions used to communicate the Brand Experience Proposition also required improvements; the focus on the concept of Design Principles hindered the development of a more experiential expression of the Brand Experience Proposition.

Theoretical advancements also emerged. During this iteration, the bidirectional link between Customer Experience and Branding became more evident, and the role of Service (Dominant) Logic in designing for service became clearer (Kimbell 2011; Sangiorgi 2012).

\subsection{Fourth design iteration: full application}

To cope with the limitations of the previous project, this iteration advanced and applied a full Branslation process, improving the Brand Experience Manual and the metaphors used to convey the Brand Experience Proposition. The iteration took place over a period of 2 months, and an organizational partner was invited to host and support the project. Thanks to the positive feedback from the previous cycle, a mid-sized telecom brand ${ }^{4}$ agreed to commit the resources necessary to enable the execution of a full Brandslation process in a setting similar to a consulting project.

For this project, the Brandslation framework was structured as a series of eight workshops divided into two phases: the Insight phase and the Development phase (Fig. 3). The Insight phase built on the learnings from the second iteration, comprising four workshops (based on the aforementioned intersection) and a series of interviews meant to inform the second session. The Development phase focused on translating the researcher data into the Brand Experience Proposition through a series of four sequential workshops, advancing the third iteration's process. A fundamental improvement was the involvement of key stakeholders, such as employees and customers, in the process.

\footnotetext{
4 The brand was part of a greater telecom corporation.
} 


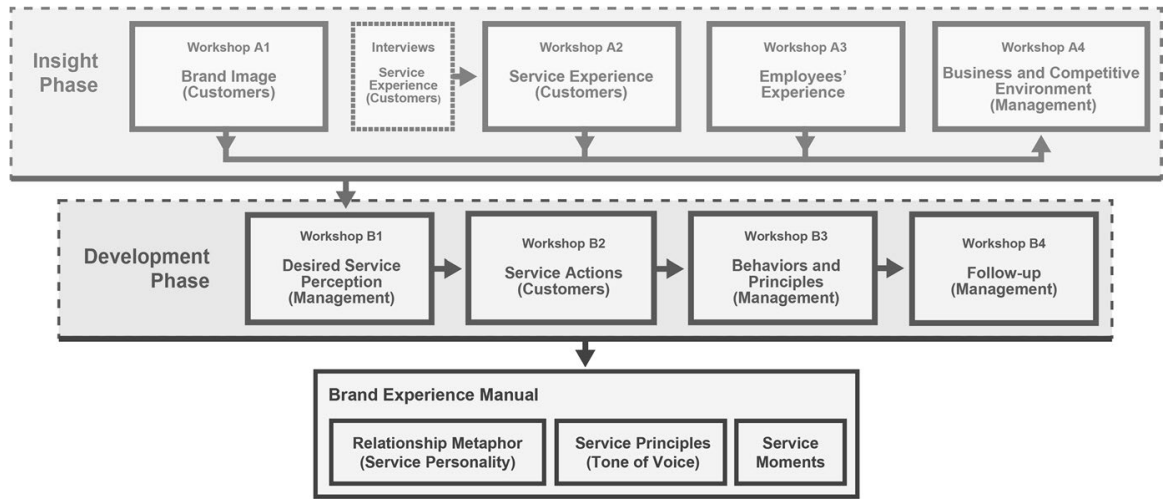

Fig. 3 Brandslation process as planned for the 4th iteration (Motta-Filho 2017)

The iteration was in many ways similar to the previous one: the (author-) researcher was the main instrument for data collection and analysis (Merriam 2002; Pinto and Santos 2008), and workshops based on "quasi-focus-group" interviews (Gaskell 2008) and participant observation (Adler and Adler 1994) were the main methods for collecting data. Official documentation and marketing insights provided by the company (Creswell 2009) helped to inform the workshop development, and a participatory approach (Kindon et al. 2007) enabled the collaborative practices that supported the execution of the Brandslation framework.

The main challenge for this iteration was to find ways to convey the desired experience the brand seeks to deliver. By framing the brand as an active partner to the customer (Fournier 1998) and building on the concept of Service Personality (Clatworthy 2012), this iteration framed the Brand Experience Proposition through the analogy of the relationship between the brand as a character and a customer persona; although the concept of Relationship Metaphor was only structured later, the idea was clearly conceived in this iteration.

Additionally, the development of better Service Principles (previously Design Principles) and the addition of Service Moments ${ }^{5}$ enabled a better balance between descriptive and prescriptive expressions to be achieved. By the end of the iteration, a fully functional data-based Brand Experience Manual was created; the Brandslation framework was improved and a research (Insight) phase was added; and insights about the process of Designing for Brand Experience reflected upon (though this last one to a lesser degree).

\subsubsection{Evaluation}

The goal of this research was to produce knowledge through the design process (Saikaly 2005; Fallman 2007) while bridging the gap between brand strategy and the

\footnotetext{
5 Not to be confused with Koivisto's (2009) concept of a similar name.
} 
NSD process by developing a new artifact. To assess the relevance of the Brand Experience Manual and the Brandslation framework, the outcomes of the last iteration were evaluated through semi-structured interviews (Fontana and Frey 1994) with experts in the field and stakeholders participating in the project.

The Brand Experience Manual was considered an effective tool for bridging the gap between the brand and the NSD process, and the Brandslation framework was praised for its collaborative and participatory approach, providing the corporate partner with insights otherwise unattainable. Criticism and limitations were also reported. The most pressing issues found were related to implementation, as the corporate partner had difficulties understanding how to use the Brand Experience Manual. For example, they wanted to apply the Service Moments (narratives meant to convey the desired experience) as guidelines for customer service. However, the Brand Experience Manual is a tool for Service Designers - an acknowledged limitation that must be addressed in future research.

The Service Principles (guidelines that inform how to design for the experience) were also criticized as being too generic. Yet, in hindsight, it was realized that this problem mainly relates to the emergent nature of the ideas; as different organizations might share similar challenges, the Service Principles might be similar, while they are actually guidelines specific to the organization at a particular moment and context. Lastly, it is important to note that the concept of creating a brand-based customer experience is not completely new, and literature on this topic is available (Smith and Wheeler 2002; Abbing 2010). The novelty of the present research is to explore the nature of the brand experience, systematizing a process for defining and a tool for conveying the Brand Experience Proposition.

\subsection{Final reflection: specifying learnings}

In the final stage of the action research (Susman and Evered 1978), the findings from the four iterations and from theory were integrated through reflection on action (Schön 1982) and writing as reflection (Richardson 1994), putting the lessons of this study into perspective. The key insights revolved around how to define (Brandslation framework) and convey the Brand Experience Proposition, and the need to advance an experience-oriented Semantic Transformation process. As these are the main outcomes of this research, they are further elaborated in the sections below.

\section{The Brandslation framework and the brand experience manual}

In this section, we present the process used to define and the tool used to communicate the Brand Experience Proposition developed through the design iterations and advanced during the reflection stages. The Brandslation framework and the Brand Experience Manual are key contributions to practice and trigger important theoretical advances discussed in Research Findings. Hence, describing these outcomes will also help ground the arguments discussed in later chapters. 


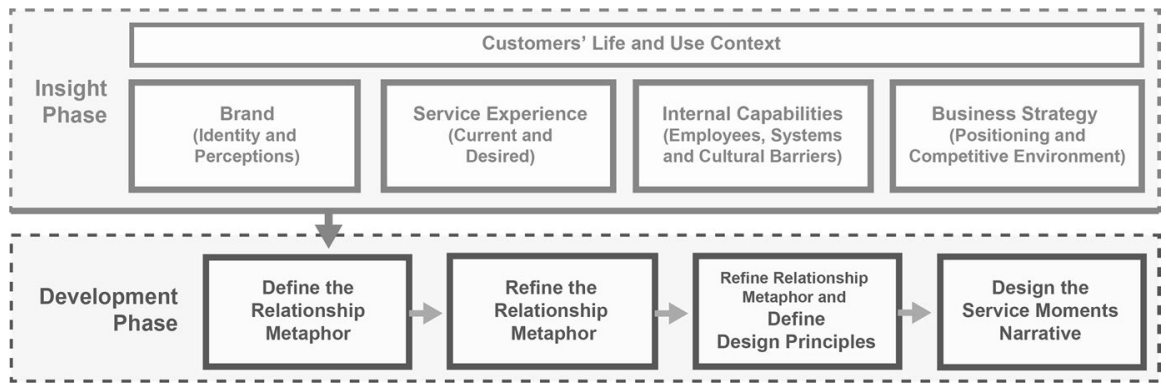

Fig. 4 The Brandslation framework (Motta-Filho 2017)

\subsection{The Brandslation framework}

The Brandslation framework is essentially a means to an end, as the actual goal is to define the Brand Experience Proposition and develop the Brand Experience Manual. Yet, because organizations do not define their brands experientially, the Brandslation framework is an indispensable first step in the process of translating brand strategy into customer experiences. The Brandslation framework is divided into two parts: during the Insight Phase, data relevant to understand the various stakeholders' (customers, employees, managers, and the organization) views of the brand and of the service are collected through a mix of qualitative methods. These insights inform the Development Phase, where the Brand Experience Proposition is created in cooperation with customers and members of the organization. In this process, the importance of customer involvement cannot be overestimated, and the role of employees must also not be overlooked.

Building on service and corporate branding theory (Harris and de Chernatony 2001; de Chernatony and Segal-Horn 2003; Schultz 2005), it is understood that brands emerge in the intersection among internal, external and interactive marketing actions (Brodie et al. 2006), requiring the involvement of the entire organization on the delivery of its promise (McDonald et al. 2001). This means that the Brandslation framework should involve multiple stakeholders in a collaborative and transdisciplinary (Dunin-Woyseth and Nilsson 2011) codesign process similar to participatory action research (Kindon et al. 2007). By involving customers, employees, and management teams, the Brandslation framework enables a rich exploration of the brand, its key relationships, and the organization behind it, supporting the development of a Brand Experience Proposition that is desirable, feasible, and viable (Brown and Katz 2009).

In the next section, we present the structure for the Brandslation framework. However, instead of describing the design interventions as executed, this section explains the Brandslation framework through a conceptual lens. That is, the focus is not on detailing the steps (how to do), but on the type of information (Insight Phase) and on the procedures (Development Phase) necessary to define the Brand Experience Proposition (what to do), thus facilitating adaptations to new contexts (Fig. 4). 


\subsubsection{Insight phase}

The Insight phase focuses on five 'arenas', each concerned with a specific aspect of the brand experience: customers' life and use context; the brand identity and image; customers' experience with the service; the internal capabilities of the organization; and the brand and business strategy. However, in practice, these categories blend, and the workshop structure can also be adjusted based on who the participants are. For example, a session aimed at exploring the brand image is also an opportunity to enquire about current customers' experiences. Similarly, a workshop with employees should focus on their experiences, but can also consider their understanding of customers. The goal is to explore the different elements that influence customers' experience with the brand.

- Customer context - the Brandslation framework essentially develops a brandbased customer experience proposition. Therefore, understanding the context in which customers interact with the service is key, for customers are seen as active actors in the value cocreation process (Vargo and Akaka 2009; Vargo et al. 2010). Customers' use context can be explored in various ways. For example, during a session, one of the exercises investigated what (e.g., SMS, data, call), when and where they used telecom services. Another possibility is to inquire about workshops with employees; as key facilitators of customer experiences, front line staff can provide rich insights into customers.

- Brand identity and image - the concept of brand can be framed from two main perspectives: from the customers' point of view, the brand image can be understood as meaning associations linked to the brand name as the result of past experiences (Aaker 1991; Kapferer 2011; Keller 2013); from the company's, the brand identity refers to the meaning proposition made by the organization, as expressed through their offerings (Aaker and Joachimsthaler 2000; Semprini 2006). The brand thus conveys insights about the relationships between the organization and customers, and the organization's current strategy. As the goal is to translate brand strategy into an experiential expression of the brand, understanding brand identity, and how customers perceive the brand is essential to ensuring that the Brand Experience Proposition is feasible and desirable.

- Service experience - the brand image reflects customers' past interactions with the organization, while the service experience refers to customers' current interactions with the brand manifestations. As lived experiences inform the memories with which customers will evaluate the brand (Kahneman 2011), and because brand equity is highly influenced by their experience with the service (Berry 2000), any type of service interaction - whether planned or not—has a significant impact on in the brand. Consequently, understanding the status of customers' experience with the service is a key factor in the process of defining a desirable Brand Experience Proposition.

- Internal capabilities - services can be understood as capacities embedded in and enabled by a dynamic configuration of resources that facilitate the process of value cocreation (Vargo et al. 2008; Maglio et al. 2009). That is, the value cocreation process is enabled by the internal capabilities of the company; in the 
context of the Brandslation framework, three key aspects must be addressed: the organizational culture, the employees' experiences (as internal customers), and the internal systems (processes and technologies). Understanding the resources that enable the service interactions will ensure the development of a feasible Brand Experience Proposition.

- Business strategy-brand and business strategy are strongly related (Aaker and Joachimsthaler 2000). The organization must be sure to allocate resources to enable the delivery of the brand proposition, as "an empty brand promise is worse than no promise at all" (ibid., p. 8). External factors, and especially how the company responds to them, will also influence customers' experiences with the brand. Hence, the balance between the competitive environment, internal competencies and value networks (Normann and Ramirez 1994), and the resulting positioning (Porter 2002), are crucial to the viability of the Brand Experience Proposition.

\subsubsection{Development phase}

Through a sequence of four design iterations, the insights acquired in the previous phase are used to inform the development of the Brand Experience Proposition and thus the Brand Experience Manual. The process begins with the creation of an analogy for the relationship the brand seeks to develop with customers (Dumas 1994): the Relationship Metaphor (details in the next section). This experiential expression of the brand is then reviewed by customers and later translated into two supplementary mediums to convey the Brand Experience Proposition: the Service Principles and the Service Moments. Before the first workshop takes place, findings from the Insight Phase and the Brand Identity must be structured in a visual and accessible way. Additionally, to support the development of the Relationship Metaphor, a research-based Customer Persona is also required.

- Define the brand character and the relationship metaphor-undoubtedly the most important part of the entire process, it is during this first iteration that the main expression of the Brand Experience Proposition is created: namely, the Relationship Metaphor. The goal is to devise a balanced Brand Experience Proposition that considers the perspectives of different stakeholders. Building on the concept of Service Personality (Clatworthy 2012), the process begins with the formulation of the Brand Character as a manifestation of who the brand would be as a person. Later, the Brand Character is described in relation to a customer persona, resulting in the Relationship Metaphor. It is important to note that the persona of the customer might not necessarily be the average user, but one that best expresses the desired relationship.

- Refine the relationship metaphor and create a customer journey-although the development of the Relationship Metaphor was based on insights from various stakeholders, it is still defined from the company's (and its managers') perspective. This second iteration involves customers fine-tuning the Relationship Metaphor and devising a customer journey based on the Relationship Metaphor. At this point, ensuring that previous work is not overhauled is a challenge, as the 
goal is to refine and not to recreate the Relationship Metaphor. The same is true for Customer Journey: participants must focus on the Relationship Metaphor so that the outcome stays within the frame of the brand (Urde 1999).

- Settle the relationship metaphor and create the design principles-the main objective of this iteration is to develop the Service Principles, which comprise a set of prescriptive expressions (guidelines) that inform the design teams of consistent patterns that support the delivery of the Brand Experience Proposition. However, the Relationship Metaphor, which at this point is the main representation of the Brand Experience Proposition, must first be formulated and a shared vision established. Next, a new customer journey map should be drawn, expressing how the Relationship Metaphor (and hence the Brand Experience Proposition) would ideally be manifested throughout service interactions. The Service Principles emerge from the analysis of the gaps between the current and the desired experience.

- Design the service movement narrative-with the Relationship Metaphor and the Service Principles, the Brand Experience Proposition is already conveyed through descriptive and prescriptive means; however, due to their nature, these expressions can be difficult to grasp. In this design iteration, the goal is to create an experiential expression for the Brand Experience Proposition through the development of a narrative that serves as a proxy for the desired experience. In other words, use storytelling to make the audience 'experience' the Brand Experience Proposition. To help structure the narrative, the service journey is broken down into Service Moments: clusters of interactions that are larger than a single service encounter but smaller than the entire journey.

\subsection{The brand experience manual}

The Brand Experience Manual is a tool meant to convey the Brand Experience Proposition to the NSD teams. It is therefore important to acknowledge the influence of the Brandslation framework on its format and how both concepts evolved in tandem throughout the research. The central challenge for the development of the Brand Experience Manual was finding how to convey the Brand Experience Proposition. Because experiences are phenomenological events (Helkkula 2011) — that is, "internal and subjective response customers have to any direct or indirect contact with a company" (Meyer and Schwager 2007, p. 2) - they cannot be designed but only designed for (Vargo and Lusch 2008; Vargo et al. 2008; Kimbell 2011; Sangiorgi 2012). Yet, experiences-like services — can be conveyed as conceptual propositions; surrogate expressions (Blomkvist 2015) communicating how the customer experience should be.

The Brand Experience Manual focuses on conveying the Brand Experience Proposition through a mix of prescriptive and descriptive expressions, with special attention to the usability of brand descriptors (Abbing 2010). As an expression of the Brand Experience Proposition, the Brand Experience Manual serves as a shareable point of reference (Giordano et al. 2018) that, by combining different types of representations, help convey a rather abstract concept (Blomkvist and Segelström 


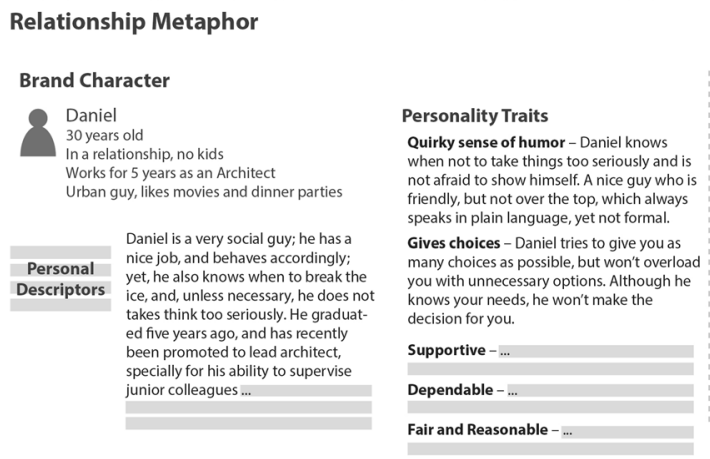

Customer Persona:

Jane

25-years-old man, single, no kids

Recently graduated; junior UX Designer Likes music concerts and socializing

Relationship Description

Jane met Daniel 5 years ago when she joined the college. Daniel was her sponsor - the responsible senior student that introduced her to the life in campus - and they clicked really quickly, as they share much of the same interest, and especially because of their sense of humor. Over the years the re and they are still in contact advises advises

Fig. 5 Example of a relationship metaphor (Motta-Filho 2017)

2014) - the desired customer experience with the brand. The goal is to support the Semantic Transformation process by providing the NSD teams with adequate input about the (brand) experience they should design for, thus enabling the translation of the brand strategy into customer experiences. The elements of the Brand Experience Manual are described in the following sections.

\subsubsection{The relationship metaphor}

The Relationship Metaphor is the most representative expression of the Brand Experience Proposition. Through the analogy of a relationship between the brand-represented by a character - and a customer persona, the Relationship Metaphor enables the creation of "a shared mental model" (Dumas 1994, p. 76), thus advancing the concept of Service Personality (Clatworthy 2012) into a more detailed and contextualized expression of the experience the brand seeks to deliver. The logic behind the concept is that in trying to deliver a brand-based customer experience, the organization is actually trying to design interactions that strengthen the relationship between the costumers (represented by the persona) and the brand (character).

The Relationship Metaphor uses a combination of descriptors that together provide a full picture of the desired relationship between the customer and the brand, thus conveying the Brand Experience Proposition. The figure below provides an example based on the outcome of the last design intervention of the research process (Fig. 5).

\subsubsection{Service principles}

While the Relationship Metaphor provides a descriptive expression of the Brand Experience Proposition-that is, it conveys how the experience should be-the Service Principles provide prescriptive guidelines meant to support the NSD teams during the design process. The goal is to bridge the gap between the existing and the desired customer experience by addressing the main shortcomings of the service. In practical terms, this means a set of six to ten actions that should be consistently 


\section{Design Principles \\ Empower the Customer to Stay In Control \\ 'brand' helps Jane to gain ownership over her choices. He helps her make the right choices by providing the best advice and information, but he doesn't make decisions for her. \\ Let the customer choose the services and subscriptions by herself Make real time and detailed consumption tracking available \\ Enable the customer to solve problems by herself \\ - Give the customer the right information to make a choice \\ Make sure the customers know djuice has got their back \\ Provide the best coverage and data connection \\ Provide Multiple Choices \\ 'brand' always shows Jane different ways of doing something. He provides different options for her to choose. There are not so many that she gets confused, but enough that she can decide which one fits her needs best. \\ Aim at offering customizable subscriptions \\ Provide multiple support channels \\ Extend the availability of extra services \\ Give customers choices, but avoid being overwhelming \\ Allow the same outcome to be achieved through alternative means}

Fig. 6 Example of two design principles based on the relationship metaphor presented above (MottaFilho 2017)

\section{Service Moments}

\begin{abstract}
Jane wants a new phone. While looking fo the new model, she finds an interactive kiosk and goes there to try it. The kiosk shows Jane a quiz that helps her choose the right phone and subscription. She found the interaction very easy and quirky and the explanations very clear, making her feel secure about her choice.

It's been a while since Jane took a trip, and she decided it's time to finally visit Morocco. She has been taken off guard with roaming charges before, and wants to be more careful this time. She decides to try the travel wizard. She opens the app and types in when and where she is going Almost instantly she gets the best solution for the journey, putting her at ease to focus on he other details for her trip.
\end{abstract}

\begin{abstract}
A few days after getting her new phone, Jane gets a mail with her new SIM card. The welcome package explains the services and asks her to choose the SIM card transfer date. Right at the agreed time, the phone starts working and a message with a cat picture welcomes her; Jane feels in control and also amused by the brand.
\end{abstract}

$$
\begin{aligned}
& \text { Jane's phone has been behaving weirdly } \\
& \text { for a few days. She starts a chat with } \\
& \text { customer support. Daniel, the support } \\
& \text { employee, thought it would be easier to } \\
& \text { explain over the phone, so he calls her. } \\
& \text { They found that the problem was on } \\
& \text { her handset and he e-mails all the details } \\
& \text { on how to proceed. The integrated support } \\
& \text { made a great impression on Jane and } \\
& \text { made her feel much more secure. }
\end{aligned}
$$

After almost one month Jane receives a message suggesting to make adjustments to her subscription. She opens the app and the wizard advises her to choose a larger subscription plan. Jane knows last month was an exception and stays with her current plan. She feels empowered by having such great control over the services.

$$
\begin{aligned}
& \text { Jane just heard about a great offer and } \\
& \text { now she also wants a new phone. She's } \\
& \text { pretty sure this offer is only valid for new } \\
& \text { customers, but she decides to give it a try. } \\
& \text { She calls ready for a fight. But to her } \\
& \text { surprise, as soon as she mentions the offer, } \\
& \text { Daniel asks if she is interested. He also tells } \\
& \text { Jane that since she is a loyal customer, he } \\
& \text { can put her on the priority list, making her } \\
& \text { feel really appreciated. }
\end{aligned}
$$

Fig. 7 Example of service moments based on the relationship metaphor and design principles presented above (Motta-Filho 2017)

enacted throughout the design process. Lastly, because the Service Principles are based on a comparison between the ideal (Relationship Metaphor-based) and the current customer journey, the insights into customers' experiences should be used to provide practical examples (Fig. 6).

\subsubsection{Service moments}

Like the Relationship Metaphor, Service Moments are descriptive expressions of the Brand Experience Proposition. The goal is to create a proxy through which the audience may experience how the ideal brand-based customer experience should be. Communicated through a narrative, the Service Moments follow a timeframe that is longer than a service encounter but shorter than a service journey, thus allowing for a balance between fragmentation and depth, which also means that the story must convey the desired experience but should not be excessively detailed. It is also important to remember that the objective is to convey a feeling: it is not about designing the service offering but conveying the desired perception (Fig. 7). 
In the next chapter, the lessons emerging from the practice-based design research are presented and discussed, thus clarifying the relevance of the iterative approach used to produce new knowledge for practice and theory.

\section{Research Findings}

To bridge the gap between brand strategy and the NSD process, this research focused on developing a Brand Experience Manual as a tool for conveying the experience proposition made by the brand. However, because organizations do not frame their brands experientially (Motta-Filho 2012), a process for defining the Brand Experience Proposition must first be developed. In that sense, the processes of devising the Brandslation framework and the Brand Experience Manual were intrinsically intertwined, which created a situation where the Brand Experience Manual was contingent on the Brandslation framework, itself dependent on the structure necessary to convey the Brand Experience Proposition, which was in turn based on the configuration of the Brand Experience Manual.

In this context, a practice-based design research (Nowotny 2004; Saikaly 2005) based on an action research strategy (Lau 1997; Susman and Evered 1978; Crouch and Pearce 2012) established the foundations for a Research through Design approach (Frayling 1993; Jonas 2007) essential for coping with a research question in which a paradoxical design situation (Dorst 2006) forced the researcher to focus on developing the object (Brand Experience Manual), while there was no known working principle (means to define and structure the Brand Experience Proposition) to support the desired outcome (Dorst 2010) — that is, to convey the Brand Experience Proposition to the NSD teams.

\subsection{The Brandslation framework and the brand experience manual}

Although practice-based design research traditionally focuses on creating new knowledge in the context of application (Nowotny 2004; Saikaly 2005) and not on developing new artifacts (Fallman 2007), the nature of the present research required developing a new artifact to bridge the gap between brand strategy and the NSD process. Hence, the Brandslation framework and the Brand Experience Manual are not only a means to an end-that is, instruments for exploring how to convey the brand strategy to the NSD team - but key outcomes of the present research, with high practical relevance.

As customer experience becomes central to developing a competitive advantage (Shaw and Ivens 2002; Prahalad and Ramaswamy 2004; Gentile et al. 2007; Johnston and Kong 2011; Manning and Bodine 2012), tools to support the design of superior service interactions become necessary. Yet, while many studies focus on customers' experiences from a theoretical perspective, "tools aimed at supporting marketing managers in devising the right stimuli to support an excellent Customer Experience are still scarce" (Gentile et al. 2007, p. 395). The Brandslation framework and the Brand Experience Manual thus make an important contribution, 
integrating Brand Strategy and Service Design into a tool that may support the development of better brand experiences for customers.

One challenge that must be addressed in the future is to make the Brandslation framework friendlier to non-designers. Because the Brandslation framework was developed through and for Service Design interventions, it is designer oriented. However, NSD teams do not always include design professionals, and managers with no design expertise often lead projects. Hence, the Brandslation framework must be integrated in a designerly practice for non-designers (Sangiorgi et al. 2019), helping ensure its continuity and implementation (Wetter-Edman and Malmberg 2016). Moreover, active participation from all stakeholders involved in the process is necessary to ensure an adequate outcome. A simpler approach could help foster engagement, especially during the workshop sessions. As such, further research and advancements on the Brandslation framework are advised.

\subsection{Conveying the brand experience proposition}

Another important outcome of the research was structuring a means of conveying the Brand Experience Proposition. Because of the phenomenological nature of experiences (Helkkula 2011), we attempted an interpretation of the Brand Experience Proposition as a conceptual meaning proposition. Brands emerge in the negotiations between a company's proposition and customers' perception (de Chernatony and Riley 1998); they are both a repository and the source of the meanings (Sherry 2005) that are mediated by customers' experiences. Hence, a Brand Experience Proposition is understood as the expression of the experience the brand wants customers to have.

For this research, the main challenge was to find the right way to express a Brand Experience Proposition while also developing a process to define it and establishing an adequate structure for the Brand Experience Manual. The expression of the Brand Experience Proposition detailed in the next sub-sections provides not only a new approach to conveying the brand but also suggests a more experiential perspective on the concept.

\subsubsection{The relationship metaphor}

The concept of Service Personality (Clatworthy 2012) exerted a strong influence throughout our research, steering the design process toward developing a humanized expression of the Brand Experience Proposition. Yet, during the last iteration cycle, when a movie analogy was used to frame the Brand Character as an active partner in the relationship with the customer (Fournier 1998), the idea of the Relationship Metaphor emerged as an evolution of the Service Personality, offering a more nuanced and contextualized expression of the Brand Experience Proposition.

However, despite the pertinence of the concept, its potential was only realized much later. When the fourth design iteration was concluded, references to the relationship between the Brand Character and the Customer Persona were often used to explain the Brand Experience Proposition, but only implicitly. It was only in the 
reflection stages, after returning to the literature, that the relevance of the Relationship Metaphor became clear. In that context, the role of customers' experiences in creating value for the brand and the anthropomorphizing of brand relationships help explain the concept.

First, one must keep in mind that the brand value (equity) is based on the meaning associations linked to the brand name, which is the outcome of customers' interaction with the brand (Aaker 1991; Semprini 2006; Kapferer 2011; Keller 2013). Because relationships are built over time throughout multiple interactions, they also reflect customers' past experience with the brand (Fournier 1998), expressing the same meaning associations that create value for the brand. To create value for the brand, therefore, the organization must focus on strengthening customers' relationship with the brand by developing service interactions that deliver brand-aligned experiences.

Second, since customers have little difficulty in associating human characteristics to a brand (Aaker 1997), as long as the brand behaves as an active partner through their marketing actions, customers will build relationships with them (de Chernatony 2010), inferring human traits in the process (Fournier 1998). Consequently, customers can easily anthropomorphize their relationships with the brand. The Relationship Metaphor conveys the Brand Experience Proposition through the analogy of a relationship between a humanized representation of the brand (i.e., the Brand Character) and a customer persona. The idea is that by replicating the Relationship Metaphor, the NSD teams will embed the Brand Experience Proposition into the service experience.

\subsubsection{Auxiliary expressions of the brand experience proposition}

Throughout the research, it became clear that an adequate articulation of the Brand Experience Proposition would require supplementary types of expression. Therefore, in addition to the Relationship Metaphor, Service Principles and Service Moments ${ }^{6}$ are also used to help convey the Brand Experience Proposition to the NSD teams. Conveying a 'desired customer experience' is a rather abstract feat. In that sense, the combination of different types of representation facilitates the communication (Blomkvist and Segelström 2014) of the Brand Experience Proposition.

The Service Principles emerged in the second design intervention while collaborating with a design consultancy. At that time, the goal was to make the brand's (Service) Personality Traits and Behaviors - thus the main representation of the Brand Experience Proposition-more tangible through guidelines that could explain to the NSD teams how to design for the desired brand experience. In the third iteration, the Service Principles (i.e., Design Principles) became the core of the Brand Experience Manual; however, these were mainly representations of the brand's Personality Traits and Behaviors. It was only in the last iteration that an approach to creating the Service Principles was established by building on the gap between the existing and the desired customer experience.

\footnotetext{
${ }^{6}$ Again, not to be confused with Koivisto's (2009) concept of a similar name.
} 
The Service Moments emerged in the last design iteration as an evolution of the narrative developed in the previous cycle, which was created as an effort to make the expression of the Brand Experience Manual more experiential. The Service Moments' purpose is to create an experiential proxy for the Brand Experience Proposition. By translating the Relationship Metaphor and Service Principles into the story of the customers' journey across different use contexts, the Service Moments help express the experience the brand wants customers to have. However, it is important to note that Service Moments are not guidelines; the idea is to create the feeling of how the experience should be, not to redesign the service.

Conceptualized as fragments of the customer journey, Service Moments are based on a timeframe that is greater than a service encounter and shorter than the customer journey. Hence the conceptual timeframe can be useful not only for expressing the Brand Experience Proposition but also in designing service experience concepts. Although touchpoints provide a practical description of the interfaces through which customers interact with the service, they miss the link between the different interactions (Polaine et al. 2013). Conversely, addressing the entire journey can be cumbersome, and projects often do not have the mandate to redesign the entire service. This way, the Service Moments provide a hybrid timeframe that can help structure experience-driven service.

\subsection{Advancing an experience-oriented semantic transformation process}

In action research, theory informs practice and practice advances theory (O'Brien 2001). Building on practice-based design research (Nowotny 2004; Saikaly 2005) based on an action research strategy (Lau 1997), it became clear in our own research that to support the implementation of the Brand Experience Manual, the current approach to Semantic Transformation (Karjalainen 2004; Clatworthy 2012) must evolve. The key issue revolves around an understanding that what is being designed is not a service per se, but rather the enablers of the service experience. Consequently, a process for designing for brand experiences should address both the front and the back end of the service innovation (Goldstein et al. 2002).

Theoretical advancements in Service (Dominant) Logic (Vargo and Lusch 2004, 2008, 2016; Grönroos 2006, 2008), and its integration with Service Design theoryspecifically the literature on Designing for Service (Evenson and Dubberly 2010; Kimbell 2011; Sangiorgi 2012; Wetter-Edman 2014; Sangiorgi and Prendiville 2017)_were integrated into a Semantic Transformation for Experience approach comprising three sub-processes: defining the Brand Experience Proposition, designing a brand experience-based service concept, and developing the processes, interfaces, and systems that deliver the service concept (Patrício et al. 2011; Kimbell and Blomberg 2017).

The conceptualization of a Semantic Transformation for Experience points to the need to address brand management from a customer experience perspective; that is, an approach focused on developing interactions through which customers experience the brand. Despite the relevance of the topic, a framework for Designing for Brand Experience is not addressed in the current paper, as it is beyond its present 
scope. Nonetheless, as the role of customer experience for businesses increases and its relevance to developing strong brands is recognized, further research on a customer experience approach to brand management is not only advised but also deemed necessary.

\section{Conclusion}

This paper addressed the gap between brand strategy and the NSD process as a means of supporting the Semantic Transformation (Karjalainen 2004; Clatworthy 2012) in a service experience context, facilitating the development of brand-based customer experiences. Through practice-based design research (Nowotny 2004; Saikaly 2005), a framework for translating brand strategy into an experiential expression of the brand proposition, and a structure for conveying the Brand Experience Proposition to the NSD teams were developed. In doing so, this paper answers the main research question: "How can we bridge the gap between the brand strategy and the NSD process?"

The Brandslation framework provides a functional approach to developing an experiential expression of the brand, and the Brand Experience Manual structures the Brand Experience Proposition in a format that is useable for the NSD teams. In combination, these outcomes provide an effective means of conveying the brand strategy to the NSD teams. Thus, the artifacts produced-the Brand Experience Manual and the Brandslation framework-are a key contribution to practice, especially in a context where tools supporting the development of superior customer experiences are scarce (Gentile et al. 2007).

Another contribution of the present research is the development of experiential expressions for the brand. The conceptualization of the Relationship Metaphor as an analogy for the experience proposition made by the brand offers a new approach to conveying the brand, one that focuses on the interactions through which customers experience the brand. Because brands emerge from interactions with customers, and their value is based on customers' perceptions (Kapferer 2011), a design process that supports the development of interactions that deliver brand-based experiences does in fact reinforce customers' relationship with the brand and also brand equity. Thus, in designing for the Relationship Metaphor, the NSD teams are actually devising interactions that deliver the customer experience the brand wants the customer to have.

The research also produced two other relevant representations of the Brand Experience Proposition: Design Principles and Service Moments. Developing the Design Principles was central to advancing the Brand Experience Manual, whereas the Service Moments provided not only a new expression but also a reference timeframe for the Service Design process.

For managers interested in exploring and defining what experience their brands should aim for, we advise to:

1. Explore the customers' perceptions of the brand and their experiences with the service. 
2. Understand how the brand is manifested from inside-out; how the internal collaborators see the brand, and how they see their role in expressing it.

3. Review the alignment between business strategy and brand positioning, and between brand identity and the customers' view of the brand.

4. Balance who the brand is (from the perspective of the customers) and who it thinks it is (from the perspective of the company), devising an experience vision that is desirable, viable and feasible.

5. Convey this brand experientially, informing the teams responsible for devising the interaction through which the customers experience the brand what experience they should aim for (as addressed in this paper).

6. Support these teams and their actions, enabling the brand experience to become alive.

On the theoretical level, the paper argues for an experience-centric approach to branding (Merrilees 2017), proposing Brand Experience Proposition as a concept for expressing the brand in an experiential way, thus providing the basis for further exploration of the experiential nature of brands. In doing so, the present research argues for further research on the intersection among Branding, Service Design and Service (Dominant) Logic as a means of advancing Service Branding: a customerexperience approach to brand management that is superordinate to goods and/or services (Brodie et al. 2009) and which focuses on integrating resources that facilitate the value cocreating interactions (i.e., value co-creating systems; Kimbell and Blomberg 2017) through which customers experience a brand.

Lastly, it is worth noting that the use of practice-based design research in a business context and the description of the process provide an example for future research aimed at developing new solutions in a practice context-that is, at answering "how can" research questions. However, this methodological approach also has its limitations. The produced artifact could not be fully implemented and tested as it was originally devised during the research process. Thus, although the Brand Experience Manual provides an experiential expression of the brand that links brand strategy and the NSD process, due to its novelty there is no data to support comparison with existing tools to convey the brand.

Acknowledgements This paper builds on a team effort involving master's degree students from the Oslo School of Architecture and Design, consultants, professionals, and academics that contributed with their time, sharing their experiences and actively engaging in the design and research processes. Their support was essential for the research presented in this paper, and the author would like to acknowledge and thank for their contribution. The author would also like to acknowledge the role of the CSI consortium in partially funding the present research. Finally, the authors would like to thank the anonymous reviewers for their insightful feedback.

Open Access This article is licensed under a Creative Commons Attribution 4.0 International License, which permits use, sharing, adaptation, distribution and reproduction in any medium or format, as long as you give appropriate credit to the original author(s) and the source, provide a link to the Creative Commons licence, and indicate if changes were made. The images or other third party material in this article are included in the article's Creative Commons licence, unless indicated otherwise in a credit line to the material. If material is not included in the article's Creative Commons licence and your intended use is not permitted by statutory regulation or exceeds the permitted use, you will need to obtain permission 
directly from the copyright holder. To view a copy of this licence, visit http://creativecommons.org/licen ses/by/4.0/.

\section{References}

Aaker D (1991) Managing brand equity: capitalizing on the value of a brand name. Free Press, New York Aaker D (1996) Building strong brands. Free Press, New York

Aaker JL (1997) Dimensions of brand personality. J Mark Res 34(3):347-356

Aaker D, Joachimsthaler E (2000) Brand leadership. Free Press, New York

Abbing ER (2010) Brand-driven innovation: strategies for development and design. AVA Publishing SA, Lausanne

Adler PA, Adler P (1994) Observational techniques. In: Denzin NK, Lincoln YS (eds) Handbook of qualitative research. Sage, Thousand Oaks, pp 377-392

Arnould EJ, Price LL (1993) River magic: extraordinary experience and the extended service encounter. J Consum Res 20(1):24-45

Batey M (2008) Brand meaning. Routledge, New York

Berry LL (2000) Cultivating service brand equity. J Acad Mark Sci 28(1):128-137

Blomkvist J (2015) Ways of seeing service: surrogates for a design material. In: Proceedings of the nordic design research conference, pp 1-4

Blomkvist J, Segelström F (2014) Benefits of external representations in service design: a distributed cognition perspective. Des J 17(3):331-346

Blomkvist J, Holmlid S, Segelström F (2010) Service design research: yesterday, today and tomorrow. In: Stickdorn M, Schneider J (eds) This is service design thinking: basics-tools-cases. BIS Publishers, Amsterdam, pp 308-315

Blomkvist J, Clatworthy S, Holmlid S (2016) Ways of seeing the design material of service. In: Proceedings of the ServDes. 2016 conference "service design geographies", pp 1-13

Brodie RJ, Glynn MS, Little V (2006) The service brand and the service-dominant logic: missing fundamental premise or the need for stronger theory? Mark Theory 6(3):363-379

Brodie RJ, Whittome JR, Brush GJ (2009) Investigating the service brand: a customer value perspective. J Bus Res 62(3):345-355

Brown T, Katz B (2009) Change by design. Harper Business, New York

Calkins T (2005) The challenge of branding. In: Tybout AM, Calkins T (eds) Kellogg on branding. Wiley, New Jersey, pp 1-8

Clatworthy S (2012) Bridging the gap between brand strategy and customer experience. Manag Serv Qual 22(2):108-127

Clatworthy S (2013) Design support at the front end of the new service development (NSD) process: the role of touch-points and service personality in supporting team work and innovation processes. Dissertation, Oslo School of Architecture and Design

Creswell JW (2009) Research design: qualitative, quantitative, and mixed methods approaches. Sage, Thousand Oaks

Cross N (1999) Design research: a disciplined conversation. Des Issues 15(2):5-10

Cross N (2010) Design thinking as a form of intelligence. In: Proceedings of the 8th design thinking research symposium (DTRS8) - interpreting design thinking, pp 99-105

Crouch C, Pearce J (2012) Doing research in design. Berg, London

De Chernatony L (2010) From brand vision to brand evaluation: the strategic process of growing and strengthening brands. Butterworth-Heinemann, Oxford

De Chernatony L, Riley FD (1998) Defining a "Brand": beyond the literature with experts' interpretation. J Mark Manag 14(5):417-443

De Chernatony L, Segal-Horn S (2003) The criteria for successful services brands. Eur J Mark 37(7/8):1095-1118

De Chernatony L, Drury S, Segal-Horn S (2003) Building a services brand: stages, people and orientations. Serv Ind J 23(3):1-21

Dorst K (2006) Design problems and design paradoxes. Des Issues 22(3):4-17

Dorst K (2010) The nature of design thinking. In: Proceedings of the 8th design thinking research symposium (DTRS8)—interpreting design thinking, pp 131-139 
Dumas A (1994) Building totems: metaphor-making in product development. Des Manag J 5(1):71-82

Dunin-Woyseth H, Nilsson F (2011) Building (trans)disciplinary architectural research-introducing mode 1 and mode 2 to design practitioners. In: Doucet I, Janssens N (eds) Transdisciplinary knowledge production in architecture and urbanism: towards hybrid modes of inquiry. Springer, Berlin, pp 79-96

Edvardsson B, Olsson J (1996) Key concepts for new service development. Serv Ind J 16(2):140-164

Ehn P (2008) Participation in design things. In: Proceedings of the tenth anniversary conference on participatory design, pp 92-101

Evenson S, Dubberly H (2010) Designing for service: creating an experience advantage. In: Salvendy G, Karwowski W (eds) Introduction to service engineering. Wiley, Hoboken, pp 403-413

Fallman D (2007) Why research-oriented design isn't design-oriented research: on the tensions between design and research in an implicit design discipline. Knowl Technol Pol 20(3):193-200

Fallman D (2008) The interaction design research triangle of design practice, design studies, and design exploration. Des Issues 24(3):4-18

Fontana F, Frey JH (1994) Interviewing: the art of science. In: Denzin NK, Lincoln YS (eds) Handbook of qualitative research. SAGE, Thousand Oaks, pp 361-376

Fournier S (1998) Consumers and their brands: developing relationship theory in consumer research. J Consum Res 24(4):343-353

Frayling C (1993) Research in art and design. R Coll Art Res Pap 1(1):1-5

Gaskell G (2008) Entrevistas individuais e grupais. In: Bauer MW, Gaskell G (eds) Pesquisa qualitativa com Texto, Imagem e Som: Um manual prático. Editora Vozes, Petrópolis, pp 64-89

Gentile C, Spiller N, Noci G (2007) How to sustain the customer experience: an overview of experience components that co-create value with the customer. Eur Manag J 25(5):395-410

Gibbons M, Limoges C, Nowotny H, Schwartzman S, Scott P, Trow M (1994) The new production of knowledge: the dynamics of science and research in contemporary societies. Sage, London

Giordano F, Morelli N, De Götzen A, Hunziker J (2018) The stakeholder map: a conversation tool for designing people-led public services. In: Proceedings of the ServDes. 2018 conference "service design proof of concept", pp 582-597

Goldstein SM, Johnston R, Duffy J, Rao J (2002) The service concept: the missing link in service design research? J Oper Manag 20(2):121-134

Grönroos C (2006) Adopting a service logic for marketing. Mark Theory 6(3):317-333

Grönroos C (2007) Service management and marketing: customer management in service competition. Wiley, West Sussex

Grönroos C (2008) Service logic revisited: who creates value? And who co-creates? Eur Bus Rev 20(4):298-314

Grönroos C, Gummerus J (2014) The service revolution and its marketing implications: service logic vs service-dominant logic. Manag Serv Qual 24(3):206-229

Grönroos C, Voima P (2013) Critical service logic: making sense of value creation and co-creation. J Acad Mark 41(2):133-150

Harris F, de Chernatony L (2001) Corporate branding and corporate brand performance. Eur J Mark 35(3/4):441-456

Helkkula A (2011) Characterising the concept of service experience. J Serv Manag 22(3):367-389

Holbrook MB, Hirschman EC (1982) The experiential aspects of consumption: consumer fantasies, feelings, and fun. J Consum Res 9(2):132-140

Holmlid A, Wetter-Edman K, Edvardsson B (2017) Breaking free from NSD: design and service beyond new service development. In: Sangiorgi D, Prendiville A (eds) Designing for service: key issues and new directions. Bloomsbury, London, pp 95-104

Iglesias O, Bonet E (2012) Persuasive brand management: how managers can influence brand meaning when they are losing control over it. J Org Manag 25(2):251-264

Johnston R, Kong X (2011) The customer experience: a road-map for improvement. Manag Serv Qual 2(1):5-24

Jonas W (2007) Design research and its meaning to the methodological development of the discipline. In: Michel R (ed) Design research now: essays and selected projects. Birkhäuser, Basel, pp 187-206

Kahneman D (2011) Thinking, fast and slow. Macmillan, New York

Kahneman D, Riis J (2005) Living, and thinking about it: two perspectives on life. In: Huppert FA, Baylis N, Keverne B (eds) The science of well-being. Oxford University Press, Oxford, pp 285-304 
Kapferer J (2011) The new strategic brand management: creating and sustaining brand equity long term, 4th edn. Kogan Page, London

Karjalainen TM (2004) Semantic transformation in design: communicating strategic brand identity through product design references. University of Art and Design Helsinki, Helsinki

Karjalainen TM (2007) It looks like a Toyota: educational approaches to designing for visual brand recognition. Int J Des 1(1):67-81

Karjalainen TM, Snelders D (2010) Designing visual recognition for the brand. J Prod Inn Manag 27(2):6-22

Keller KL (2013) Strategic brand management building, measuring, and managing brand equity, 4th edn. Global Edition, Pearson

Kemmis A, McTaggart R (2008) Participatory action research: communicative action and the public sphere. In: Denzin NK, Lincoln YS (eds) Strategies of qualitative inquiry, 2nd edn. Sage, Thousand Oaks, pp 271-330

Kimbell L (2009) The turn to service design. In: Julier G, Moor L (eds) Design and creativity: policy, management and practice. Berg, Oxford, pp 157-173

Kimbell L (2011) Designing for service as one way of designing services. Int J Des 5(2):41-52

Kimbell and Blomberg (2017) The object of service design. In: Sangiorgi D, Prendiville A (eds) Designing for service: key issues and new directions. Bloomsbury, London, pp 81-94

Kindon S, Pain R, Kesby M (2007) Participatory action research: origins, approaches and methods. In: Kindon S, Pain R, Kesby M (eds) Participatory action research approaches and methods: connecting people, participation and place. Routledge, New York, pp 9-18

Koivisto M (2009) Frameworks for structuring services and customer experiences. In: Miettinen S, Koivisto M (eds) Designing services with innovative methods, Kuopio academy of design, Keuruu, pp 136-149

Krippendorff K (1989) On the essential contexts of artifacts or on the proposition that "design is making sense (of things)". Des Issues 5(2):9-39

Lau F (1997) A review on the use of action research in information systems studies. In: Lee AS, Liebenau J, DeGross JI (eds) Information systems and qualitative research. Springer, Boston, pp 31-68

Mager B (2009) Service design as an emerging field. In: Miettinen S, Koivisto M (eds) Designing services with innovative methods. Taik Publications, Helsinki, pp 28-42

Maglio PP, Vargo SL, Caswell N, Spohrer J (2009) The service system is the basic abstraction of service science. Inf Syst E-Bus Manag 7(4):395-406

Manning H, Bodine K (2012) Outside in: the power of putting customers at the center of your business. Houghton Mifflin Harcourt, New Harvest

Manzini E (2009) Service design in the age of networks and sustainability. In: Miettinen S, Koivisto M (eds) Designing services with innovative methods. Taik Publications, Helsinki, pp 44-59

Manzini E (2011) Introduction. In: Meroni A, Sangiorgi D (eds) Design for services. Gower Publishing, Aldershot, pp 1-6

McDonald MHB, De Chernatony L, Harris F (2001) Corporate marketing and service brands—moving beyond the fast-moving consumer goods model. Eur J Mark 35(3/4):335-352

Meenaghan T (1995) The role of advertising in brand image development. J Prod Brand Manag 4(4):23-34

Merriam SB (2002) Introduction to qualitative research. In: Merriam SB (ed) Qualitative research in practice: examples for discussion and analysis, 1st edn. Jossey-Bass, San Francisco, pp 3-16

Merrilees B (2017) Experience-centric branding: challenges and advancing a new mantra for corporate brand governance. J Brand Manag 24(1):1-13

Merz MA, He Y, Vargo SL (2009) The evolving brand logic: a service-dominant logic perspective. J Acad Mark Sci 37(3):328-344

Meyer C, Schwager A (2007) Understanding customer experience. Harvard Bus Rev 85:1-11

Moritz S (2005) Service design. Practical access to an evolving field. Köln International School of Design, Köln

Morrison S, Crane FG (2007) Building the service brand by creating and managing an emotional brand experience. J Brand Manag 14(5):410-421

Motta-Filho, MA (2012) The brand experience manual: addressing the gap between brand strategy and new service development. In: Proceedings from the 2012 international design management research conference, pp 671-680

Motta-Filho MA (2017) Designing for brand experience: operationalizing a service dominant logic approach to branding through service design. Ph.D.Thesis, Akademika, Oslo 
Munchbach C (2014) The convergence of brand, customer experience, and marketing. Forrester Research, Cambridge

Normann R, Ramirez R (1994) Designing interactive strategy: from value chain to value constellation. Wiley, Chichester

Nowotny H (2004) The potential of transdisciplinarity. In: Dunin-Woyseth H, Nielsen LM (eds) Discussing transdisciplinarity: making profession and the new mode of knowledge production: the nordic reader. The Oslo School of Architecture and Design, Oslo, pp 10-18

O'Brien R (2001) An overview of the methodological approach of action research. In: Richardson R (ed) Theory and practice of action research. Universidade Federal da Paraíba, João Pessoa

Ostrum AL, Iacobucci D, Morgan FN (1995) Services branding. In: Tybout AM, Calkins T (eds) Kellogg on branding. Willey, Hoboken, pp 186-200

Overkamp T, Holmlid S (2016) Views on implementation and how they could be used in service design. In: Proceedings of the ServDes. 2016 conference "service design geographies", pp 205-214

Patrício L, Fisk RP, Constantine L (2011) Multilevel service design: from customer value constellation to service experience blueprinting. J Serv Res 14(2):180-200

Patrício L, Teixeira JG, Vink J (2019) A service design approach to healthcare innovation: from decisionmaking to sense-making and institutional change. AMS Rev 9(1/2):115-120

Pine BJ, Gilmore JH (1998) Welcome to the experience economy. Harvard Bus Rev 76:97-105

Pinto MR, Santos LLS (2008) Em busca de uma trilha interpretativista para a pesquisa do consumidor: uma proposta baseada na fenomenologia, na etnografia e na grounded theory. RAE-Eletrôn $7(2): 1676-5648$

Plumeyer A, Kottemann P, Böger D, Decker R (2019) Measuring brand image: a systematic review, practical guidance, and future research directions. Rev Manag Sci 13(2):227-265

Polaine A, Løvlie L, Reason B (2013) Service design. From implementation to practice. Reosenfeld Media, New York

Porter ME (2002) Different views of strategy. In: Mazzucato M (ed) Strategy for business: a reader, 1st edn. SAGE, London, pp 10-31

Prahalad CK, Ramaswamy V (2004) Co-creation experiences: the next practice in value creation. J Interact Mark 18(3):5-14

Reason P, Bradbury H (2008) Introduction. In: Reason P, Bradbury H (eds) The SAGE handbook of action research: participative inquiry and practice, 2nd edn. Sage, London, pp 1-10

Richardson L (1994) Writing: a method of inquiry. In: Denzin NK, Lincoln YS (eds) Handbook of qualitative research. SAGE, Thousand Oaks, pp 516-529

Saikaly F (2005) Approaches to design research: towards the designerly way. In: Sixth international conference of the european academy of design (EAD06). University of the Arts, Bremen, Germany

Sangiorgi D (2012) Value co-creation in design for service. In: Miettinen S, Valtonen A (eds) Service design with theory. Lapland University, Vantaa, pp 97-106

Sangiorgi D, Prendiville A (2017) Designing for service: key issues and new directions. Bloomsbury, New York

Sangiorgi D, Lima F, Patrício L, Joly MP, Favini C (2019) A human-centred, multidisciplinary, and transformative approach to service science: a service design perspective. In: Maglio PP, Kieliszewski CA, Spohrer JC, Lyons K, Patrício L, Sawatani Y (eds) Handbook of service science, vol 2. Springer, Berlin, pp 147-181

Santaella L (2008) Semiótica Aplicada. Cengage Learning, São Paulo

Schmidt K, Ludlow C (2001) Inclusive branding: the why and how of a holistic approach to brands. Palgrave Macmillan, Basingstoke

Schmitt BH (1999) Experiential marketing. J Mark Manag 15(1-3):53-67

Schmitt BH (2003) Customer experience management: a revolutionary approach to connecting with your customers. Willey, Hoboken

Schön DA (1982) The reflective practitioner: how professionals think in action. Basic Books, New York

Schultz M (2005) A cross-disciplinary perspective on corporate branding. In: Schultz M, Antorini YM, Csaba FF (eds) Corporate branding: purpose/people/process. Copenhagen Business School Press, Gylling, pp 23-55

Secomandi F, Snelders D (2011) The object of service design. Des Issues 27(3):20-34

Segelström F (2013) Stakeholder engagement for service design: how service designers identify and communicate insights. Linköping University Electronic Press, Linköping

Semprini A (2006) A Marca Pós-Moderna: poder e Fragilidade da Marca na Sociedade Contemporânea. Estação das Letras, São Paulo 
Sevaldson B (2010) Discussions and movements in design research: a systems approach to practice research in design. Form Akad 3(1):8-35

Shaw C, Ivens J (2002) Building great customer experiences. Palgrave Macmillan, Basingstoke

Sherry JF (2005) Brand meaning. In: Tybout AM, Calkins T (eds) Kellogg on branding. Wiley, Hoboken, pp 40-69

Shostack GL (1977) Breaking free from product marketing. J Mark 41(2):73-80

Smith S, Wheeler J (2002) Managing the customer experience: turning customers into advocates. Prentice Hall, London

Stappers P, Giaccardi E (2017) Research through design. In: The encyclopedia of human-computer interaction, pp 1-94

Stickdorn M (2010) 5 Principles. In: Stickdorn M, Schneider J (eds) This is service design thinking: basics-tools-cases. BIS Publishers, Amsterdam, pp 34-45

Sundbo J, Sørensen F (2013) Introduction to experience economy. In: Sundbo J, Sørensen F (eds) Handbook on the experience economy. Edward Elgar, Cheltenham, pp 1-20

Susman GI, Evered RD (1978) An assessment of the scientific merits of action research. Adm Sci Q 23(4):582-603

Tatikonda MV, Zeithaml VA (2002) Managing the new service development process: multi-disciplinary literature synthesis and directions for future research. In: Boone T, Ganeshan R (eds) New directions in supply-chain management. Amacom, New York, pp 200-233

Urde M (1999) Brand orientation: a mindset for building brands into strategic resources. J Mark Manag 1(3):117-133

Vargo SL (2008) Customer integration and value creation paradigmatic traps and perspectives. J Serv Res 11(2):211-215

Vargo SL, Akaka MA (2009) Service-dominant logic as a foundation for service science: clarifications. Serv Sci 1(1):32-41

Vargo SL, Lusch RF (2004) Evolving to a new dominant logic for marketing. J Mark 68(1):1-17

Vargo SL, Lusch RF (2008) Service-dominant logic: continuing the evolution. J Acad Mark Sci 36(1):1-10

Vargo SL, Lusch RF (2016) Institutions and axioms: an extension and update of service-dominant logic. J Acad Mark Sci 44(1):5-23

Vargo SL, Maglio PP, Akaka MA (2008) On value and value co-creation: a service systems and service logic perspective. Eur Manag J 26(3):145-152

Vargo SL, Lusch RF, Akaka MA, He Y (2010) The service-dominant logic of marketing: a review and assessment. Rev Mark Res 6(2):125-167

Verganti R (2009) Design driven innovation: changing the rules of competition by radically innovating what things mean. Harvard Business Press, Boston

Wetter-Edman K (2011) Service design: a conceptualization of an emerging practice. University of Gothenburg, Gothenburg

Wetter-Edman K (2014) Design for service: a framework for articulating designers' contribution as interpreter of users' experience. Art Monitor, Gothenburg

Wetter-Edman K, Malmberg L (2016) Experience and expertise: key issues for developing innovation capabilities through service design. In: Proceedings of the ServDes. 2016 conference "service design geographies", pp 516-521

Yu E, Sangiorgi D (2014) Service design as an approach to new service development: reflections and futures studies. In: ServDes 2014 fourth service design and innovation conference "service futures", pp 194-204

Yu E, Sangiorgi D (2018) Service design as an approach to implement the value cocreation perspective in new service development. J Serv Res 21(1):40-58

Zomerdijk LG, Voss CA (2010) Service design for experience-centric services. J Serv Res 13(1):67-82

Publisher's Note Springer Nature remains neutral with regard to jurisdictional claims in published maps and institutional affiliations. 